\title{
Openbaring 21:1-8 in teks en prediking
}

\begin{abstract}
Author:
Gerhard Bothma ${ }^{1}$

\section{Affiliation:}

${ }^{1}$ Department Practical

Theology, University of

Pretoria, South Africa

\section{Correspondence to:}

Gerhard Bothma

Email:

gerliese@mweb.co.za

Postal address:

PO Box 436, Fauna Park

Za-0787, South Africa

Dates:

Received: 19 Jan. 2015

Accepted: 09 July 2015

Published: 31 Aug. 2015

How to cite this article:

Bothma, G., 2015,

'Openbaring 21:1-8 in teks en prediking', In die Skriflig 49(2), Art. \#1932, 8 pages. http://dx.doi.org/10.4102/ ids.v49i2.1932

\section{Copyright:}

(C) 2015. The Authors. Licensee: AOSIS

OpenJournals. This work is licensed under the Creative Commons Attribution License.
\end{abstract}

\section{Read online:}

Openbaring 21:1-8 bring 'n belangrike wending in hierdie boek. Die koms van 'n nuwe hemel, 'n nuwe aarde en 'n nuwe Jerusalem word aangekondig. Die oue is verby. Die nuwe het gekom. Hoe behoort Openbaring 21:1-8 uitgelê, vertolk en verstaan te word? Hoe behoort daar oor hierdie teks gepreek te word? Hierdie en nog meer vrae word in hierdie artikel bespreek. Vanweë onder andere die literêre genre daarvan, stel die boek Openbaring unieke uitdagings aan diegene wat dit wil uitlê, verstaan en daaroor wil preek. Deur Openbaring 21:1-8 en homiletiese teorie met mekaar in verband te bring, word hierdie Skrifgedeelte vir die prediking ontgin. Deur die benutting van 'n literêr-estetiese benadering tot prediking in 'n skuiwende kultuur - soos deur Cas Vos en Cas Wepener ontwikkel - word die nuwe hemel en aarde, die nuwe Jerusalem en die lied 'Hot Gates' met mekaar gekombineer om nuwe betekenismoontlikhede te ontdek. Deur intertekstueel en inkulturerend te werk te gaan, word parameters vir die uitleg en verstaan van Openbaring 21:1-8 geformuleer en voorstelle vir die prediking van hierdie Skrifgedeelte word gemaak.

Revelation 21:1-8 in text and preaching. Revelation 21:1-8 presents an important turning point in this book. A new heaven, a new earth and a New Jerusalem are introduced. The old has passed. The new has come. How should Revelation 21:1-8 be read, interpreted and understood? How should this text be preached? These and other questions are asked in this article. Because of its literary genre, amongst other factors, the Book of Revelation poses unique challenges to anyone who wants to interpret and understand or preach about it. Revelation 21:1-8 is investigated by engaging the text and homiletic theory with each other. By utilising a literary-esthetical approach to preaching in a changing culture - as developed by Cas Vos en Cas Wepener - the new heaven and earth, the new Jerusalem and the song 'Hot Gates' are engaged with one another in order to find possible new meanings. By working intertextually and inculturating, parameters for the explanation and understanding of Revelation 21:1-8 are explicated and suggestions with regard to preaching this text are made.

\section{Inleiding en probleemstelling}

Volgens Du Rand (2007) bring Openbaring 21:1-8 'n belangrike wending in hierdie boek. Hy skryf soos volg hieroor:

Hierdie agt verse sluit God se oordeelsvoltrekking af en dien ook as skarnier na die opwindende aanbreek van die nuwe era, wat in 21:9-27 met beeldspraak as die nuwe Jerusalem beskryf word, en in 22:1-5 as die nuwe Eden. (bl. 578)

Openbaring 21:1-8 word 'gesien as 'n finale afsluiting van die strafperiode: 19:6-21:8' en is ook 'die inleiding tot 21:9-22:5 wat vertel van die nuwe verlossing wat vir gelowiges aanbreek' (Du Rand 2007:578).

Roloff (1993, loc. 3420-3423) beskryf 21:1 tot 22:5 as 'God se nuwe wêreld' waarmee God se handelinge hulle doel bereik en 21:1-8 as 'God se nuwe skeppingshandeling'. Volgens hom word ' $n$ algemene oorsig oor die nuwe skepping as gebeure gegee in 21:1-8. Hiernaas word in 21:922:5 'a close-up picture, as it were, of the decisive aspect: the perfected salvation community as the new Jerusalem' uitgesonder (Roloff 1993, loc. 3423).

Oor die lees, uitleg en verstaan van die Openbaringboek is alreeds baie nagedink en geskryf (sien Du Rand 1990a:295-313; 2007:660-667; Barr 2012, loc. 6031-6687) vir 'n uitgebreide leeslys). Professor Jan A. du Rand se bydrae op wetenskaplike, populêr-wetenskaplike sowel as populêre vlak in hierdie verband is wyd bekend (Du Rand 1990a:300-301; 2007:662-664). Veral in Afrikaans 
het hy 'n onberekenbare waardevolle bydrae tot die lees en verstaan van Openbaring gemaak (Du Rand 1990a; 1996; 2007; 2013).

Deur dít wat al oor Openbaring geskryf is te bestudeer, kan daar vasgestel word hoe Openbaring gelees, uitgelê en verstaan moet word. Meer as een teorie vir die lees, uitlê en verstaan van die Openbaringboek is al geformuleer en sal nog geformuleer kan word. Daar sal ook teorieë geformuleer kan word oor hoe oor Openbaring gepreek en/of behoort gepreek te word. Net so sal daar ook vasgestel kan word hoe daar binne spesifieke kontekste in die praktyk tans oor Openbaring gepreek word.

Kommentaar na aanleiding van navorsing oor die gedeelte sowel as gepubliseerde preke en voorstelle vir prediking is volop (sien die lys van geraadpleegde werke). In hierdie artikel word met spesifieke verwysing na 21:1-8 aandag geskenk aan wat al oor die lees, uitleg, verstaan en die prediking van Openbaring geskryf is.

Die probleemstelling hou verband met die teks en prediking van 21:1-8 en kan in terme van twee navorsingsvrae soos volg geformuleer word: Hoe behoort 21:1-8 gelees, uitgelê en verstaan te word? en Hoe kan of behoort oor Openbaring 21:1-8 in die praktyk gepreek te word?

In 'n informele, voorlopige ondersoek na antwoorde op hierdie vrae is die navorser se vermoede bevestig dat daar 'n leemte in die navorsing oor die verband tussen Openbaring en prediking bestaan. Met hierdie navorsing word gepoog om hierdie leemte vul.

\section{Metodologie}

Die metodologiese weg wat ingeslaan word om die probleemstelling te beantwoord, is om uit die literatuur wat oor die lees, uitleg en verstaan van 21:1-8 bestaan by hermeneutiese en homiletiese riglyne uit te kom wat as rigtingwysers vir die prediking van Openbaring sou kon dien. Dit val buite die skopus van hierdie artikel om 'n empiriese ondersoek te doen na dít wat in die praktyk oor hierdie teksgedeelte gepreek word.

Eerstens word gepoog om 21:1-8 as teksgedeelte beter te verstaan. Die vraag oor hoe 21:1-8 gelees, uitgelê en verstaan behoort te word, word hier aan die bod gebring. Parameters vir die lees, uitleg en verstaan van die teks word van nader beskou.

Tweedens word gepoog om vas te stel hoe daar oor 21:1-8 in die praktyk gepreek behoort te word. Cas Vos en Cas Wepener (2014) ontwikkel 'n literêr-estetiese benadering tot prediking (en liturgiek) in 'n skuiwende kultuur. Ná 'n beskrywing en beoordeling van hierdie benadering word dit toegepas deur 21:1-8 en Christopher Torr se lied 'Hot Gates' (1993; Afrikaanse lied 2008) aan die hand van hierdie homiletiese proses met mekaar te gekombineer. Deur die gebruik van intertekstuele en inkulturerende prosesse word dus gepoog om by nuwe betekenismoontlikhede uit te kom.

Laastens word konkrete voorstelle vir die prediking van 21:1-8 gemaak en 'n kort preekskets geformuleer.

\section{Agtergrond vir die lees, uitleg en verstaan van Openbaring as sodanig}

Cloete en Smit (1992:56) maak 'n belangrike opmerking wanneer hulle stel dat Openbaring presies soos al die ander Bybelboeke gelees moet word: in die eerste plek met inagneming van die feit dat dit aan die destydse lesers gerig is sowel as van die genre waarin dit geskryf is.

Volgens Du Rand (2007:17-27) is Openbaring 'n apokalips (1:1), 'n brief (1:3) en 'n profesie (1:4-6). Dit bevat apokaliptiese eskatologie, profetiese vorme, liturgiese materiaal en edikte. Daar is ook 'n wye verskeidenheid literêre tegnieke, soos die verspreiding van simbole en beelde regdeur die boek, aankondigings wat later ontwikkel word, kruisverwysings, kontraste, numeriese strukture, tussenspelle, insetsels en kombinasies van hierdie tegnieke (vgl. ook Duling 2003: 456-457).

Met betrekking tot die skrywer van Openbaring stel Du Rand (1990a) dit soos volg:

Oor die historiese identiteit van die outeur van Openbaring kan bloot gesê word dat dit 'n Johannes is wat uit die Johannese tradisies, waarskynlik in Klein-Asië, geput het en van wie ons nie iets meer met sekerheid kan sê nie. (bl. 19)

Die skrywer van die boek identifiseer homself bloot as 'Johannes', die 'broer' van sy lesers aan wie hy skryf $(1: 1,9)$. Hy noem homself 'n 'dienaar' (doulos) van Jesus Christus en 'n getuie (marturion) van dit wat aan hom gesê en bevestig is (1:1-2). Aune (1981) is van mening dat Johannes 'n profeet en dalk nog deel van 'n profetiese groep of orde kon wees. Du Rand (1990a:192) voeg hierby dat Johannes beslis 'n Christen en waarskynlik 'n rondgaande apokaliptiese profeet was wat die omstandighede van die gemeentes aan wie hy skryf, goed geken het. Hy moes minstens met Grieks, Misjna-Hebreeus en die Joodse spreektaal, Aramees, goed bekend gewees het.

Die Griekse woord apokalypsis word as 'openbaring' ('revelation') vertaal. Die werkwoordvorm van die woord (apokalypto) is algemeen gebruik vir die betekenis om geheime bekend te maak (Malina \& Pilch 2000:2; Smith 1983:12; ook Du Rand 1990a:164-184). In die Openbaringboek is dit dieselfde God wat aan die Ou-Testamentiese profete verskyn het en wat Homself in en deur die profeet Johannes sowel as deur die beskrywings in die boek bekendmaak (Du Rand 2007:19, 205-207).

Wanneer die Openbaringboek gelees word, is dit goed om die inleiding daarvan in gedagte te hou. In 1:1-2 word gestel dat God die openbaring aan Jesus Christus gegee het; Jesus Christus het dit aan die engel gegee; die engel het dit aan 
Johannes gegee en Johannes het dit aan die gemeentes gegee. Wat God gekommunikeer wou hê, is gekommunikeer. God se doel is daarom bereik.

\section{Die samestelling van die Openbaringboek en die plek van 21:1-8 daarin}

Du Rand (1990a:251) skryf dat daar soveel indelings vir die samestelling en opbou van die Openbaringboek is as wat daar verklaringsmoontlikhede voor is. Nadat hy 'n aantal moontlike indelings van die Openbaringboek asook sommige van die redes daarvoor en dinge wat in ag geneem moet word met die indeling daarvan bespreek het, kies hy ' $n$ narratiewe indeling binne die raamwerk van drie Christologiese bedrywe (Du Rand 1990a:251-271).

Die eerste bedryf (hoofstukke 1-3) handel oor God se teenwoordigheid deur die verheerlikte Christus in die kerk. In die tweede bedryf (hoofstukke 4-11) ontplooi God verlossing en oordeel in die wêreld deur die Lam wat die seëls van die boekrol oopmaak. In die derde bedryf (hoofstukke 12-22) ontvou God verlossing en oordeel in die geskiedenis, wat op die vernietiging van Babilon uitloop en dui op die nuwe Jerusalem as bruid (Du Rand 1990a:269$270 ; 2007: 44-47)$.

In die aanloop tot 21:1-8 sien Johannes 'n groot oop ruimte in die hemel. In die finale reeks openbarings, verduidelik Johannes wat binnekort hierdie spasie in die hemelruim gaan vul. Hierdie reeks tekste bevat vier gesigte: Eerstens sien Johannes ' $n$ algemene prentjie van die herstelde wêreld (v. 1-2) en 'n neerdalende Jerusalem (v. 3-8). Hierna vertel hy wat hy gesien het terwyl die nuwe Jerusalem aan hom gewys is (v. 9-21). Hy kry ook 'n nader kykie na die tempel en die troon van God en die Lam in die stad (21:22-22:1-5; Du Rand 2007:578-588; Malina \& Pilch 2000:244-246; Myburgh \& Mullins 2002:229-233).

Volgens Blount (2009, loc. 6269-6273) bied Johannes se visioene van die toekoms etiese riglyne vir die hede. Hoe gelowiges in die hede behoort te leef, word in die visioene aan die bod gebring. Bauckham (1993, loc. 273) skryf dat die effek van Johannes se visioene is om sy lesers se wêreld, ruimtelik (in die hemel in) sowel as tydelik (in die eskatologiese toekoms in) uit te brei; met ander woorde, om dit te laat oopgaan vir goddelike transendensie.

\section{'n Uitleg en verstaan van 21:1-8}

Wat die uitleg en verstaan van Openbaring betref, noem en bespreek Du Rand (1990a:230-249, 1990b:240-245) 'n aantal verskillende interpretasiemodelle en -teorieë. Dit val egter buite die skopus van hierdie artikel. Dieselfde geld vir 'n detail-analise van die Griekse teks en grammatika. Kommentare soos dié van Aune (1997), Bauckham (1993), Mounce (1977) en andere, kan hieroor geraadpleeg word (sien ook Du Rand 1990a:226).
In 21:1 vertel Johannes van die kosmostransformasie. Dit is 'n tema wat deurlopend by profete soos Jesaja en Jeremia voorkom (sien bv. Jes 43:19, 65:17 en 66:22; Jer 31:22). Een van die redes waarom Johannes hierdie prentjie kon sien, is dat hierdie werklikhede volgens Israelitiese tradisie en uit hulle oogpunt alreeds by God realiteite is. God het immers die wêreld teen die einde van die skeppingsweek kláár geskep (Gen 1). Die rede waarom hier nie meer'n see is nie, is omdat dit destyds met chaos en vernietiging geassosieer is. Die see was die blyplek - en broeiplek - van monsters, goddelose magte en alles wat vuil, onrein en boos is. Dit het God se teenwoordigheid onsigbaar gemaak (Du Rand 2007:587; sien ook Barr 2012, loc. 4406-4421; Blount 2009, loc. 6268-6308; Groenewald 1986:207-208; Mounce 1977:369-370; Myburgh \& Mullins 2002:229-230).

In Jesaja 65:17-22 is God en sy volk se vreugde prominent. Die aanbreek van die nuwe hemel en die nuwe aarde is ' $n$ vreugdevolle gebeurtenis. Omdat net Gód alleen kan skep, skryf Mangina (2010:47-47), kan ook slegs Gód herskep.

In vers 2 kom daar nou, saam met die nuwe kosmos, 'n nuwe sentrum tot die kosmos, 'n werklik 'heilige stad', die nuwe Jerusalem. Die hemelse stad lyk soos 'n bruid en staan in skrille kontras met die sedelose vrou - Babilon in Openbaring 17. Alhoewel die antieke Mediterreense stede amper sonder uitsondering as vroulik voorgestel en uitgebeeld is, is dit nie waaroor hierdie beeld gaan nie. Dit sluit aan by die vorige verwysing na die hemelse bruid van die Lam en dui op wie dit moontlik kan wees. Die verhouding tussen God en sy kinders, en die Lam en sy volgelinge is net so intiem soos dié van 'n bruidegom en bruid. In hierdie beeld verteenwoordig die gelowiges ook die bruid. Die skeiding tussen hemel en aarde word opgehef (Du Rand 1990a:271, 2007:580; sien ook Blount 2009, loc. 6316-6348; Malina \& Pilch 2000:245; Mounce 1977:370-371; Myburgh \& Mullins 2002:230).

In 21:3 word Jerusalem aangekondig as die plek waar God sy 'tent' by sy mense opslaan. Al die lesers en hoorders sou onmiddelik aan die tentwonings in die woestyn saam met Moses gedink het (Eks 33:7; 40:34). Die hemelse stad is God se nuwe woonplek tussen menslike wesens. Israel se heiligdom was die plek van God se teenwoordigheid (Gen 28:16) waar Hy tussen die Israeliete rondbeweeg het (Eks 25:8; 29:45-46; Lev 26:11-12; Ps 132:14). Die finale heiligdom sou die permanente teenwoordigheid van God aandui (Eseg 37:26-28). God woon deur sy Gees ín mense om Homself déúr mense te vertoon. Die meervoud in Esegiël 37:28 is opvallend: hulle sal sy volke wees. God is by meer as net die Israeliete van ouds teenwoordig. 'n Subtiele grammatiese skuif verteenwoordig 'n groot teologiese skuif weg van die spesifieke na die universele. Deur sy Gees help God ook om die seer, sukkel en swaarkry draaglik en uiteindelik héél te maak (Du Rand 2007:583-584; sien ook Blount 2009, loc. 6348-6364; Malina \& Pilch 2000:245; Mounce 1977:371-372; Myburgh \& Mullins 2002:230). 
In vers 21:4 lees ons dat énigiets wat menslike welwese stuit of belemmer - van dood tot pyn - sal ophou bestaan terwyl dit saam met 'die ou dinge' (die ou hemel en die ou aarde) in die niet verdwyn (Du Rand 2007:584; vgl. ook Blount 2009, loc. 6371; Malina \& Pilch 2000:245). Hierdie stelling dien ter morele ondersteuning van Johannes se hoorders of lesers, net soos wat die lys van diegene wat aan die realiteite deelneem dit ook doen (Malina \& Pilch 2000:245; Mounce 1977:372-373; Myburgh \& Mullins 2002:230).

In verse 21:5-6 kondig God - die Een op die troon, die Alfa en die Omega, die Begin en die Einde - aan dat Hy persoonlik álles transformeer. Ons vind in verse 5 tot 8 sewe uitsprake deur God Self. Wat in 1:8 en 1:17 van Jesus gesê word, word hier van God gesê. God gee aan Johannes opdrag om alles neer te skryf, of te wel om rekord van die gebeure te hou. Laastens kondig Hy die finaliteit van die transformasie aan. Dit gaan nie miskien ééndag gebeur nie; dit het kláár gebeur. God is betroubaar en praat die waarheid: Hy en Hy alleen maak alles nuut (Du Rand 2007:584-585; vlg. ook Blount 2009, loc. 6371-6380; Malina \& Pilch 2000:244; Mounce 1977:373-374; Myburgh \& Mullins 2002:231).

In 21:7 en 8 lees ons God se laaste twee uitsprake in die gedeelte. In vers 7 word die gelowiges aangemoedig om in hulle geloof en lewe te volhard en word die verbond tussen God en mens bevestig: God is hulle God, en hulle is God se kinders. In vers 8 tref ons 'n tipiese sonde- of skandelys aan (vgl. Rom 1:29-31; 1 Kor 5:9-11; 6:9-10; Gal 5:19-21) aan. Dit is ' $n$ parenetiese tegniek wat aangewend word om lesers en hoorders aan te moedig om 'n eerbare lewe eerder as 'n skandelike lewe te lei. Deur die duidelike tweedeling in die twee verse sien ons dat die dinge wat trane, dood, leed, smart en pyn veroorsaak - bangheid, ontrouheid, losbandigheid, moord ensovoorts - nie meer sal wees nie (Du Rand 2007:584585; vgl. ook Blount 2009:6397-6421; Malina \& Pilch 2000:246; Myburgh \& Mullins 2002:232-233).

Volgens Joubert (2012:652) is dit 'God se visie vir sy nuwe wêreld' wat hier geskets word. Dít waaroor persone soos Jesaja (59:20; 65:18) en Esegiël (40-48) gedroom het, word waar. Ons het elkeen vrye toegang tot God se teenwoordigheid tot in ewigheid (Joubert 2012:653). 'Om alle sweem van twyfel te verban, verklaar God dat die dinge waarvan gepraat is, klaar gebeur het. By God is daar nie 'n verlede, hede en toekoms nie' (Groenewald 1986:209).

\section{Oor die stede in Openbaring: Tussen Rome en Jerusalem}

Die christelike wêreld van die boek Openbaring, is 'n wêreld van stede, skryf Bauckham (1993, loc. 2284). Volgens hom woon die lesers van die boek in die sewe groot stede van Klein-Asië. Johannes en baie van sy lesers het geografies en simbolies tussen Jerusalem en Rome geleef, skryf hy: 'Whether they were Jews or Gentiles, most of John's readers were used to belonging to a city' (Bauckham 1993, loc. 2321). Die meeste van hierdie lesers sou waarskynlik gedink het dat hulle slegs volledig mens kon wees indien hulle volledig deel was van die stad se openbare lewe. Veral welvarende Christene se grootste uitdagings sou wees om te onderskei aan watter praktyke van die stad hulle kon deelneem en aan watter nie. Alhoewel hulle sou wou ervaar dat hulle deel van 'n groep was en iewers behoort het deur byvoorbeeld aan die ekonomie en rituele van identiteit en burgerlike trots deel te neem, sou hulle nie aan afgodery en immoraliteit wou deelhê nie (Bauckham 1993, loc. 2321).

Die fisiese stad Jerusalem was verwoes en die ideale Rome was nie in die stede waar hulle geleef het 'n werklikheid nie. Om metafories 'uit Babilon uit' (18:4) te kon kom, het Johannes se lesers 'n alternatief nodig gehad, iewers waarheen hulle kom gaan, 'n stad waar hulle kon tuiskom. Om 'n nuwe visie - wat hulle die toekoms kon intrek - te ontwikkel, moes hulle hulself kon losmaak van Babilon se korrupterende invloed op hulle leefwêreld. Hulle vind hierdie visie in God se alternatiewe stad: die Nuwe Jerusalem wat uit die hemel uit neerdaal (Bauckham 1993, loc. 2336).

Howard-Brook en Gwyther (1999, loc. 4752-4755) skryf dat'n Babilon ontstaan waar ' $n$ menslike samelewing in 'n empire ontaard en soos God Self optree. 'n Nuwe Jerusalem ontstaan waar menslike gemeenskappe die weë van empire-wees weerstaan en God in die sentrum van hulle gemeenskapslewe stel.

Kraybill (2010, loc. 3222) skryf dat die nuwe hemel en nuwe aarde ' $n$ teenswoordige realiteit is. Hy verwys na Walter Brueggemann wat daarvan praat dat Christene hulle lewens rondom 'counterimagined worlds' - wat teenoor empire en kwaad staan - organiseer. Al is die wêreld rondom ons vol geweld en gierigheid kán ons dit - veral tydens aanbidding verbeeld soos wat God dit geskep het en herskep. Deur die Gees kan ons 'n voorsmakie van die nuwe skepping kry.

\section{Parameters vir prediking oor 21:1-8}

Müller (1985:11) beklemtoon dat eskatologiese prediking nie 'n 'noodoplossing' vir die vrae van die tyd is nie: 'dit is 'n wesenskenmerk van alle prediking'. Prediking oor Openbaring in die algemeen het altyd 'n dringende aktualiteit en 'n dreigende wêreldvreemdheid. Die núwe, komende te midde van die oue roep ons die toekoms binne. Ons preek hier 'n vreemde boodskap, 'n vreemde geregtigheid, 'n vreemde orde, 'n vreemde gemeenskap, 'n vreemde bestemming (Müller 1985:12).

Eskatologiese prediking is prediking tussen herinnering en verwagting en lui die fees van verwagting in terwyl dit uit die toekoms sin gee aan die hede én aan die verlede. Dit is gelaai met 'n aansteeklike vreugde en 'n sterk missionêre gerigtheid (Müller 1985:15-19).

Cloete en Smit (1992:61) skryf dat getroue prediking oor hierdie perikoop 'n poging moet wees om 'n alternatiewe visie op die werklikheid te proklameer. Predikers moet, volgens hulle, oor die rol wat visioene, drome, utopias en 
verbeelding oor die algemeen speel, besin en die krag van mitiese taal moet ontdek en ontgin word (Cloete \& Smit 1992:62). Simbole wat prominent in mense se gedagtewêreld is, is nie net terapeuties nie, maar speel 'n belangrike rol in die herskep van mense se toekoms. Die volgende uitdaging vir die prediking van hierdie perikoop lê daarin dat die transformatiewe krag van die alternatiewe visie op die werklikheid benut moet word (Cloete \& Smit 1992:62).

Mense se eie persoonlike eksistensiële behoeftes maak dit vir hulle moontlik om vertroostende visioene soos hierdie te waardeer (Cloete \& Smit 1992:62). Daarom moet die prediking ook vertroostend wees. Predikers moet versigtig wees met die inkulturering van troos. Hulle moet onthou dat die 'ou dinge' nie sommer vanself verby of weggaan nie. Getroue prediking oor hierdie perikoop moet in ag neem dat slegs hoorders wat hulle eie pyn en lyding belééf, die transformatiewe krag van hierdie alternatiewe visie op die werklikheid sal waardeer (Cloete \& Smit 1992:62).

Du Preez (1996) se opmerking is belangrik:

Die kerk se sending is dus nie alleen om Gods barmhartigheid teenoor mens en stad te bewys nie, maar eweseer teenoor die aarde, waarsonder mens en stad nie kan bestaan nie. (bl. 78)

Cloete en Smit (1992:64) stel dit dat 'n eerste homiletiese strategie vir die prediking oor hierdie perikoop retories van aard moet wees, naamlik vertroosting, vermaning en transformasie. Christene sál swaarkry en vervolg word omdat hulle hul dissipelskap uitleef. Hulle moet daarom deur prediking oor tekste soos hierdie versterk word en tot volharding opgeroep word. Wat transformasie betref, is passiewe weerstand ' $n$ kragtige 'wapen' teen onreg en onderdrukking. ' $n$ Vaskleef aan ons visie van 'n alternatiewe werklikheid, is nodig.

\section{'n Literêr-estetiese benadering tot prediking in 'n skuiwende kultuur}

'In die teologiese tradisie waarbinne ons staan', skryf Vos en Wepener (2014:23), 'is die heil en die viering daarvan ondenkbaar sonder 'n lewende verbinding met die Woord van God.' Dit is uiters belangrik dat die teks waaroor daar gepreek word in die prediking aan die bod kom. Die hoorder moet by die prediking betrek word en die preek moet by die hoorder - wat net soos ons tussen 'eina en amen' leef - tuiskom (Vos 1995:5). In die mens se leefwêreld, waarvan die videokultuur en kuns deel vorm, skep kuns die moontlikheid om anders te dink en te ontvang (Vos \& Wepener 2014:23).

Gerhard Ulrich (1999:73-80) skryf dat kerk en teater 'n gemeenskaplike wortel het: hulle deel dieselfde lewenstemas. Hy verwys na Aristoteles wat daarop gewys het dat drama die mens se oё en ore oopmaak en die tragedie, maar ook deernis, medelye en katarsis bewerk. Die komedie bring 'n ligtheid en verheldering van die gemoed. Al die laste word weggelag. Dít is wat die godsdiens ook wil doen.
Simboliese en poëtiese taal is belangrik omdat dit die hoorder deur die meervlakkigheid van taal tot 'n eie interpretasie aanmoedig (Otto 1987:113-118; Vos \& Wepener 2014:25). Ars praedicandi is die lewenskuns om dit te waag om van God te praat, en die preek as ars praedicandi is 'n kuns van en vir die lewe (Vos \& Wepener 2014:25-26).

In Tom Troeger se Homiletiek speel die krag van fantasie volgens Vos en Wepener (2014:27) 'n belangrike rol (vgl. ook Troeger 1990). Fantasie kan volgens Troeger aangeleer word en dit gebeur wanneer ons harte en gedagtes soos flikkerende tonge vlam. Dit gebeur as ons met oop oë deur die wêreld gaan en ons vooringenomenheid laat vaar. Troeger (1990:14) skryf, 'Feel the bodily weight of the truth and listen to the music of language' en is van mening dat die klank en die ritme van die woorde opgevang moet word. Daarom maak hy veel van musiek en poësie om die preek- en liturgiese gebeure te verryk.

Vir die formulering van 'n literêr-estetiese benadering tot prediking, leun Vos hiernaas op die werke van Thomas Long en Johan Cilliers (Vos \& Wepener 2014:68).

In sy boek The Witness of Preaching kyk Thomas Long (2005:19) na wat hy 'meester metafore' vir die prediker noem. Dit is die boodskapper, die storieverteller, die pastor en die getuie. Let ons op die boek Openbaring, sien ons dat Johannes iets van al vier hierdie metafore reflekteer. In 1:1 word Johannes as die boodskapper van 'n besonderse boodskap geskets. Hy vertel soos 'n bedrewe storieverteller wat hy gesien het en sy pastorale inslag is deurgaans - veral in 21:1-8 - opsigtelik. In 1:2 word Johannes ook 'n getuie van wat God gesê en genoem het. Daar word ook gesê dat hy van alles getuig wat hy gesien het.

Johan Cilliers (2004:65-75) maak baie van hierdie gedagte van getuig en getuie wees deur op die essensie daarvan, naamlik 'om te sien en om ander te laat sien' te fokus. Ons sien dit ook deurgaans by Johannes in die boek Openbaring. Openbaring 21:1 begin met die woorde: 'Toe het ek 'n nuwe hemel en 'n nuwe aarde gesien' en dan wys hy as 't ware met sy woorde vir sy hoorders wat hy gesien het.

Die begrip inkulturasie kom uit die kulturele antropologie en beteken 'integrasie in 'n vreemde kultuur' (Vos \& Wepener 2014:75). Die Christendom oorskry voortdurend grense en sal steeds weer en weer moet inkarneer binne nuwe sosiaal-kulturele samehange. Homiletiese teorie wil die prediker help om die kerugmatiese essensie uit die destydse bekleding los te wikkel en binne ons situasie nuut en vars te klee. Gemeentes mag nie wêreldvreemd wees nie (Vos \& Wepener 2014:75-76).

Intertekstualiteit kan beskryf word as die spore van ander tekste, of die 'gesprek' wat voortdurend tussen talle soorte tekste plaasvind. Dit dui ook op die vorming van nuwe tekste. Tekste 'skuur op mekaar af' en ons moenie nalaat om met ' $n$ teks se 'geheime dialoog' met ander tekste rekening te hou (Vos \& Wepener 2014:76). 
Prediking is bedoel om hoorders só te laat luister en mee te voer dat hulle die boodskap op die alledaagse lewe kan toepas. Die intertekstuele spel is 'n blywende en speelse wisselwerking tussen die teks wat die hoorder in die erediens ontvang en die konteks. Die spel word nou 'n lewensspel (Vos \& Wepener 2014:76).

\section{'Hot Gates'}

Christopher Torr het die lied 'Hot Gates' in 1993 geskryf. In 2008 het hy dit ook in Afrikaans verwerk.

Die lied het ' $n$ hele aantal raakvlakke met 21:1-8 en ander gedeeltes in Openbaring. 'Jerusalem', wat in die eerste strofe van die lied voorkom, verwys na die stad in Israel. In die laaste strofe word na die 'nuwe' Jerusalem - soos in 21:2 genoem - verwys. Dit is die stad wat Johannes in sy visie gesien het. In 21:21 staan geskryf: 'Die strate van die stad is van suiwer goud, blink soos 'n spieël.' Openbaring 21:1-8 en die lied 'Hot Gates' het duidelik dieselfde stad in gedagte. Die stede wat in die lied genoem word staan in skrille kontras met die ander stad waarvan die strate met goud geplavei is.

Die titel van die lied sluit aan by 'n frase in die Engelse digter, T.S. Elliot se gedig 'Gerontion' (1920): 'I was neither at the hot gates / Nor fought in the warm rain ...'

Torr het hierdie frase by Elliot oorgeneem om brandpunte uit die wêreldgeskiedenis aan te dui. 'Hot Gates' is die letterlike vertaling van die Griekse pleknaam Thermopylae. In 480 voor Christus het daar in die bergpas by Thermophylae 'n vurige veldslag tussen die Spartane en Persiese invallers plaasgevind. Hierdie veldslag het later een van die bekendste veldslae in die Westerse geskiedenis geword. Die film ' 300 ' is daarop gebaseer. Thermopylae is ook die laaste pleknaam wat in die liedjie genoem word en is gebruik as titel in die Afikaanse vertaling van die lied.

Die titel Hot Gates is 'n deurgang, 'n poort na 'n toekomstige wêreld. Die deurgange is warm omdat dit brand of nog brand. Aan veldslae kom daar nie 'n einde nie, glo baie mense.

Torr het die plekname nie willekeuring agtermekaar ingeryg nie. Elke reël vorm 'n metriese eenheid deur die gebruik van sewe lettergrepe. Hy gebruik eindrym uitstekend. Elke volgende reël se laaste lettergreep rym met die voorafgaande een. Die alliterasie en assonansie is treffend. Dit is onder andere waarneembaar by 'Srebrenica, Sebokeng, Sarajevo, o Saigon' en 'Moscow, Beijing, Tokyo.'

Die klanke word, namate die lied vorder, eksplosiewer en herinner aan kanon- en tenkskote. Dit is veral besonder treffend wanneer Torr se vrou, Laurika Rauch - vir wie hy die lied geskryf het - dit sing. 'Balaklawa, Austerlitz, Belsen, Buchenwald, Auswitch' bevat besonder eksplosiewe konsonante.

Die lied begin met: 'London, Paris, Rome, Berlin'. Met die eerste oogopslag lyk dit bloot na vier groot wêreldstede in die bakermat van die Westerse beskawing. Hoe verder die liedjie egter vorder en bekende plekname uit die tweede Wêreldoorlog of slagvelde uit die Suid-Afrikaanse geskiedenis genoem word, word dit duidelik dat die stede die feit dat hulle slagvelde is waar mense se lewens en volkere se omstandighede dwars oor die wêreld heen verander het, met mekaar in gemeen het.

Baie van die plekname wat naas mekaar geplaas word, het dikwels 'n gemeenskaplike faktor. Met 'Waco, Waco, Betlehem' word die Amerikaanse dorpie waar die sekteleier, David Koresh, homself as 'n nuwe Messias verklaar, langs die bybelse geboortedorp van Jesus, die wáre Messias, geplaas. Dit val buite die skopus van hierdie ondersoek om uitsluitsel te gee of Betlehem wél Jesus se geboortedorp was (Borg 1995:22-23; Vermes 2006:22). Wanneer die lied gesing word, klink dit asof Betlehem - waar daar kindermoorde was - geroep word om wakker te word: 'Waco, awake o Betlehem'. Die volgelinge van die ware Messias word opgeroep om wakker en op hulle hoede te wees vir valse profete soos Koresh.

Deur Sharpeville, My Lai en Boipatong met mekaar in verband te bring, vestig Torr die aandag op die lot van gewone burgers teenoor geweldadige magte waarteenoor hulle geen verweer het nie.

Met Frankfurt, New York en Lockerbie word ons herinner aan 1988. 'n Vliegtuig was vanaf Frankfurt oppad na New York. Toe 'n bom wat aan boord geplant was ontplof, val die vliegtuig en sterf al die insittendes. Nóg mense sterf wanneer die vliegtuig se wrakstukke op huise in die Skotse dorpie, Lockerbie, val.

Dunkirk, Dover en Normandy was al drie slagvelde tydens die tweede wêreldoorlog. Belsen, Buchenwald en Auschwitz is konsentrasiekampe uit dieselfde oorlog.

Verskeie plekname hou verband met die Suid-Afrikaanse geskiedenis. Amajuba was 'n slagveld tydens die AngloBoere oorlog. In Heilbron was 'n konsentrasiekamp en op St. Helena is Boere krygsgevange gehou. Suid-Afrikaanse soldate het tydens die Tweede Wêreldoorlog in NoordAfrika by El Alamein saam met die geallieerdes gaan veg. In Sebokeng, Sharpville en Mitchellsplein was daar tydens die sogenaamde 'struggle' teen Apartheid baie onrus en geweld wat tot bloedvergieting gelei het.

Naas Jerigo - waar die Israeliete in die beloofde land ingetrek het - is die tweede laaste pleknaam ook een wat in Openbaring (16:16) voorkom: Armageddon. Baie mense glo dat die laaste aardse veldslag híér gevoer sal word.

Die aaneenskakeling van plekname word met 'n refrein afgewissel. Die eerste refrein is onheilspellend: 'n vurige gloed is op die horison te sien. 'Another horseman on the run' verwys na die vier perde in Openbaring 6 en die sin, ' $O$ my daugter, o my son', vestig die aandag op die gevolge van 
hierdie veldslae op gesinne en herinner ook aan frases uit die Ou Testament.

In die tweede refrein glinster daar hoop. Ná die eindelose reeks stede waar onheil bo-op onheil gestapel word terwyl dit lyk en voel of daar geen einde in sig is nie, kom daar nou uitsig op 'n ander stad. Die nuwe Jerusalem staan in skrille kontras met die aardse Jerusalem aan die begin van die lied.

Daar is ' $n$ ander lied wat gesing gaan word én ' $n$ ander klok - as die een wat sterfgevalle aankondig - wat gelui sal word. Waar daar aan die begin van die lied 'n klok die onafwendbare verloop van tyd en onheil aandui, eindig die lied met 'n vreugdevolle, ekstatiese klokkespel. 'n Nuwe era van ewigdurende vrede en vreugde word ingelui.

\section{'n Voorgestelde preekskets}

Thompson (2010) toon in sy boek The Book of Revelation: Apocalypse and Empire (1990) aan dat daar nie noodwendig soveel gewelddadige vervolging van vroeë Christene geskied het soos wat dikwels voorgehou word nie. In die prediking is dit dus belangrik om nie net op die geweld, onreg en vergrype in stede wat in die lied genoem word te fokus nie, maar ook iets daarin wat na God se vars begin vooruitgryp, te soek.

Na aanleiding van 'n vroeëre probeerslag (Bothma 2009) kan die volgende preekskets voorgestel word:

Ons leef voor God tussen die "Hot Gates" en die Nuwe Jerusalem. Londen. Parys. Rome. Berlyn. Barcelona. Washington ...

Groot stede. Hoofstede van internasionale moonthede.

Stede waarin geskiedenis gemaak is en kulture gevorm is.

Stede waarin mense gebore en gevorm is. En misvorm is.

In elkeen van die plekke wat in Christopher Torr se lied, Hot Gates, genoem word, het dinge gebeur wat individue, gesinne en daarom ook die mensdom geraak het.

In elkeen van hierdie plekke is die gang van die lewe en die geskiedenis beïnvloed.

In elkeen van hierdie plekke het God gesien wat mense aan mekaar doen.

In elkeen van dié plekke het mense tot God geroep. Net soos óns vandag.

Elkeen van die plekname wat in die lied voorkom het 'n spesifieke betekenis.

Dis nie net internasionaal waar die geskiedenis gevorm word nie, maar ook plaaslik.

Ja, ons weet van die "fiery, fiery glow" oor Hirosjima en ons treur daaroor. Maar dis oor en vir óns dogters en seuns wat ons bid wanneer ons die ruiters swaard-in-die-hand op hul perde aangejaag sien kom.

Dit wat by Waterloo, Gettysburgh en Auschwitz gebeur het raak ons, maar het nie onder ons vel kom lê nie. Amajuba en Heilbron lê nader aan ons, maar ons kry nie nagmerries daaroor nie. Dis oor Sebokeng, Sharpeville en Boipatong waaroor ons nagmerries moet kry. Dis oor wat híer en in Mitchell's Plain gebeur het wat ons nagmerries moet gee. Ons moet hieroor ten hemele skree. Ons moet oor ons dogters en seuns wat hier gely het, ween en bid dat dit nooit weer gebeur nie.
Tussen al die lyding en leed deur is daar hoop.

Ons sien dit veral by die destydse Hot Gates van Thermopolye, toe koning Leonidas en sy Spartane die 'barbare' teruggehou het totdat die Grieke die destydse beskawing kon red.

Regdeur die lied loop 'n fyn refrein wat ook hoop bring:

Daar is ' $n$ ander lied wat gesing sal word. Daar is ' $n$ ander klok wat moet beier.

Daar's nóg 'n stad waarvan ons vertel word;'n stad waarvan die paaie gelê is met goud.

In die nuwe Jerusalem sal ons almal tuiskom.

Dáár sal ons besef die woonplek van God is by die mense (Openbaring 21:3).

In Betlehem is oor 'n seun wat gebore is geglimlag.

God se spore en vingerafdrukke is nie net hier gesien nie, maar ook by Jerigo (met die landsinname van die Israeliete) en in Babilon (ná die verlossing uit die ballingskap).

By Armagedon - so glo baie - sal Hy na die finale veldslag as oorwinnaar staan. Maar ons weet dat die oorwinning reeds behaal ís. In Jerusalem, omtrent tweeduisend jaar gelede.

In Polokwane, Pretoria, Pofadder en Perth kan ons daarom sing: "Hy sal bý hulle bly; hulle sal sy volke wees, en God self sal by hulle wees as hulle God. Hy sal al die trane van hulle oë afdroog. Die dood sal daar nie meer wees nie. Ook leed, smart en pyn sal daar nie meer wees nie" (Openbaring 21:3-4).

Nie die konings, veggeneraals, handelaars of aandeelhouers van die New York's, die godsdienstige whacko's van Waco of toesmeerders van Chappaquiddick nie, maar die Een wat op die troon sit, sê: "Kyk, Ek maak alles nuut." Ons kan dit glo, want hierdie woorde is betroubaar en waar." "Dit het klaar gebeur", het Hy gesê. Hý is "die Alfa en die Omega, die Begin en die Einde." Al word ons vermink en vermoor in die stede van die heersers (Openbaring 13), sal Hy aan elkeen wat dors het, te drinke gee uit die fontein met die water van die lewe, verniet (Openbaring 21:3-6).

Ons hoop lê nie by die heil wat ons in die stede vind nie, maar by Hóm wat geëer word met orrelspel en kerkklokke. Vir selfs langer as wat ons dit kan hoor.

Dis nie die 300 Spartane en húlle koning wat in die Hot Gates van Thermopolye gestaan het en gesneuwel het, wat die beskawing beskerm nie, maar ons "Stadsheer". Al voel dit asof die stadslewe ons vandag verswelg, lê ons krag nie in onsself nie, maar in Hóm. Anders as Leonidas se dapper volgelinge vég ons nie om 'n oorwinning nie, maar dien ons soos die Kindjie van Betlehem ... in elke stad en oord. Ons geskiedenis word omvou deur Sy geskiedenis.

Daar is ' $n$ ander lied wat gesing sál word.

Daar is 'n ander klok wat moet beier. Daar's nóg 'n stad waarvan ons vertel word;

'n stad waarvan die paaie gelê is met goud.

Ons lewe tussen die "Hot Gates" en die Nuwe Jerusalem.

Mag jy tussen jou trane deur, in jou nood en terwyl jy worstel met die probleme wat dreig om jou te oorweldig, die koel water van die lewe op jou tong proe en oor jou lyf voel spoel.

Mag jy in jou weg deur die lewe en jou opstaan vir wat goed is iets van die núwe wat God bring sien en ' $n$ voorsmakie daarvan beleef. 
Hy wat op die troon sit, die Alfa en die Omega, maak alles nuut: ook vir jou.

Hý waarborg jou tuiskoms. Hy begelei jou op jou reis. Nóú en áltyd.

\section{Samevatting}

Augustinus was van mening dat die doel van die prediking met drie trefwoorde te doen het: 'docere', 'delectare' en 'movere'. Die doel van die preek is dus om te leer, te geniet en om die hoorder te oorreed om die evangelie te aanvaar (Augustinus 1995; Vos \& Wepener 2014:28).

Kuns, soos poësie en liedere, kan met min moeite en groot sukses in die homiletiese proses benut word. 'n Literêrestetiese benadering tot die prediking is 'n geskikte manier om 21:1-8 en ander tekste nuwe betekenis gee en toeganklik te maak vir prediking. Dit kan ook daartoe bydra dat hoorders die prediking geniet.

\section{Erkenning \\ Mededingende belange}

Die outeur verklaar dat hy geen finansiële of persoonlike verbintenis met enige party het wat hom nadelig of voordelig kon beïnvloed het in die skryf van hierdie artikel nie.

\section{Literatuurverwysings}

Augustinus, 1995, 'De Doctrina Christiana', in R.P.H. Green (ed.), Oxford early Christian texts, transl. R.P.H. Green, Clarendon Press, Oxford.

Aune, D.E., 1981, 'The social matrix of the Apocalypse of John', Biblical Research 26, $16-32$.

Aune, D.E., 1997, Revelation 17-22, Nelson, Nashville. (Word Biblical Commentary, 52c).

Barr, D.L., 2012, Tales of the end. A narrative commentary on the book Revelation, Kindle edn., Polebridge Press, Salem, Oregon, viewed 11 January 2015, from http://amazon.com

Bauckham, R., 1993, The theology of the book of Revelation, Kindle edn., Cambridge University Press, Cambridge, viewed 11 January 2015, from http://amazon.com

Blount, B.K., 2009, Revelation: A commentary. (The New Testament Library), Kindle edn., Westminster John Knox Press, Louisville, Kentucky, viewed 11 January 2015 from http://amazon.com

Borg, M.J., 1995, Meeting Jesus again for the first time, Harper, San Francisco.

Bothma, G., 2009, 'Ons leef voor God tussen die "Hot Gates” en die Nuwe Jerusalem, Meditatio: Openbaring 21:1-8', Teo-webdiens, Universiteit van Pretoria, Pretoria, besigtig 10 Desember 2013, by www.http://teo.co.za/meditatioopenbaring-211-6/

Cloete, G.D. \& Smit, D.J., 1992, 'Exegesis and proclamation: “And I saw a new heaven and a new earth, for the first ... were passed away ..." (Revelation 21:1-8)', Journal of Theology for Southern Africa 81, 55-65.
Cilliers, J.H., 2004, Die lewende stem van die Evangelie. Nuut gedink oor die basiese beginsels van prediking, SUN Press, Stellenbosch.

Duling, D.C., 2003, The New Testament: History, literature and social context, Wadsworth, Thomson Learning, Belmont, CA.

Du Preez, J., 1996, 'Openbaring 21:1-8', in C.W. Burger, B.A. Müller \& D.J. Smit (reds.), Woord teen die lig 1/10; Riglyne vir sending-prediking tussen Pinkster en Advent, bl. 68-80, Lux Verbi, Kaapstad.

Du Rand, J.A., 1990a, Johannese Perspektiewe. Deel 1: Inleiding tot die Johannese Geskrifte, Orion, Midrand.

Du Rand, J.A., 1990b, 'Die Openbaring aan Johannes. A. Inleiding tot die Openbaring aan Johannes', in A.B. du Toit (red.), Handleiding by die Nuwe Testament, Band VI, Die Johannesevangelie; Hebreërs tot Openbaring: Inleiding en Teologie, bl. 219-252, NG Kerkboekhandel, Pretoria.

Du Rand, J.A., 1996, 666 en die eeuwenteling, Christelike Uitgewersmaatskappy, Vereeniging.

Du Rand, J.A., 2007, Die A-Z van Openbaring. 'n Allesomvattende perspektief op die boek Openbaring, Christelike Uitgewersmaatskappy, Vereeniging.

Du Rand, J.A., 2013, Die Einde. Die A-Z van die Bybelse boodskap oor die eindtyd, Christelike Uitgewersmaatskappy, Vereeniging.

Elliot, T.S., 1920, Poems, A.A. Knopf, New York.

Groenewald, E.P., 1986, Die Openbaring van Johannes, NG Kerk-Uitgewers, Kaapstad.

Howard-Brook, W. \& Gwyther, A., 1999, Unveiling empire: Reading revelation then and now (Bible and Liberation), Kindle edn., Orbis Books, Maryknoll, New York, viewed 11 January 2015, from http://amazon.com

Joubert, S.J., 2012, Ontsluit die Nuwe Testament. Omvattende Bybelreise vir 'n beter verstaan van die Skrif, Christelike Uitgewersmaatskappy, Vereeniging.

Kraybill, J.N., 2010, Apocalypse and allegiance: Worship, politics and devotion in the book of revelation, Kindle edn., Baker Publishing Group, Grand Rapids, Michigan, viewed 11 January 2015, from http://amazon.com.

Long, T.G., 2005, The witness of preaching, Westminster John Knox Press, Louisville.

Malina, B.J. \& Pilch, J.J., 2000, Social science commentary on the book of Revelations, Fortress, Minneapolis.

Mangina, J.L., 2010, Revelation (Brazos Theological Commentary on the Bible), Kindle edn., Baker Publishing Group, Grand Rapids, Michigan, viewed 11 January 2015, from http://amazon.com

Mounce, R.H., 1977, The book Revelation, Eerdmans, Grand Rapids. (The new International Commentary on the New Testament, 17).

Müller, B.A., 1985, 'Eskatologiese prediking', in C.W. Burger, B.A. Müller \& D.J. Smit (reds.), Woord teen die Lig 6, Riglyne vir eskatologiese prediking, bl. 9-22, NG Kerk-Uitgewers, Kaapstad.

Myburgh, J.A. \& Mullins, A., 2002, Goeie Nuus!'n Gemeente se belewenis van Openbaring, Medpharm Books, Lyttleton Manor.

Otto, G., 1987, Predigt als rhetorische Aufgabe. Homiletische Perspektive, Neukirchener Verlag, Neukirchen-Vluyn.

Roloff, R., 1993, The Revelation of John (Continental Commentary Series), Kindle edn., Fortres Press, Minneapolis, viewed 11 January 2015, from http://amazon.com

Smith, M., 1983, 'On the History of Apokalypto and Apokalypsis', in D. Helhom (ed.), Apocalypticism in the Mediterranean World and the Near East, Mohr, Tübingen.

Thompson, L.L., 2010, The book of Revelation: Apocalypse and empire, Oxford University Press, New York.

Torr, C., 1993, Hot gates, Christopher Torr, Pretoria.

Troeger, T., 1990, Imagining a sermon, Abingdon Press, Nashville.

Ulrich, G., 1999, 'Theater und Gottesdienst - Eine gemeinzame Wurzel,' in L. Mödl, H.-G. Schöttler \& G. Ulrich (Hrsg.), Das Evangelium ist eine Kraft Gottes, pp. 73-80, Don Bosco, München.

Vermes, G., 2006, The nativity: History and legend, Penguin Books, London.

Vos, C.J.A., 1995, Die blye tyding: Homiletiek uit 'n hermeneuties-kommunikatiewe persprektief, RGN-Uitgewers, Pretoria.

Vos, C.J.A. \& Wepener, C., 2014, Tussen God en mens: 'n Literêr-estetiese benadering tot liturgie en prediking in ' $n$ skuiwende kultuur, Cas Vos \& Cas Wepener, Pretoria. 